\title{
STUDENTS TRAINING TENDENCY IN THE EU AND UKRAINE: LEGAL ASPECT
}

\author{
Natalia Mospan \\ $\mathrm{PhD}$ \\ Assistant Professor of English Philology and Translation Department \\ Borys Grinchenko Kyiv University, Ukraine \\ Monavik@ukr.net \\ $+3080962323261$ \\ ORCID ID 0000-0001-8610-7965
}

\section{ABSTRACT}

The article presents the current trends in the preparation of students in higher education in the EU and Ukraine. These trends are identified on the basis of the analysis of legal documents (legal acts of primary and secondary law), which reflect the EU response to contemporary global changes in education: globalization and marketization. These processes require from higher education to provide new approaches to the training of students in accordance with labour market demands. The new Law on Higher Education in Ukraine directs the development of national higher education system to integration into the European Higher Education Area. The new law establishes financial principles of higher education system, creates conditions for strengthening cooperation of government agencies and businesses with universities on the principles of autonomy of higher educational institutions. An important goal is to prepare competitive human capital for national high-tech innovation and development, to provide the labour market with skilled workers. The author considers that the legal documents of the EU and Ukraine try to reflect the current trends in training of students in accordance with the processes of globalization and marketization in education.

Keywords: higher education; labour market; legal acts; training of students; the EU.

\section{INTRODUCTION}

In order to overcome the economic crisis the EU stared the strategy "Europe 2020", which means the European movement towards highly-developed economy with highly skilled workers. Accordingly, the future success of the EU economy depends on effective transition of graduates from higher education and training to employment, which is possible only if the graduates have appropriate training for employers demands. This situation is changing not only the role of universities in general, but the training process as well. Study of the EU experience in training students is an important practical aspect of the European integration of Ukraine. This aspect becomes clear only in the context of the analysis of modern approaches to training graduates in the EU and in Ukraine. An important step to solve this issue was the adoption of the new Law on Higher Education of Ukraine in 2014. This law is very important for the development of higher education in Ukraine, as it carries many important changes. The new law establishes financial principles of higher education system, creates conditions for strengthening cooperation of government agencies and businesses with universities on the principles of autonomy in higher education. An important goal is to prepare competitive human capital for national 
high-tech innovation and development, self-identity, provide labour market and the state with skilled professionals (Law on Higher Education of Ukraine, 2014: p. 17). Accordingly, the purpose of this article is to identify current trends in students training in the EU and in Ukraine based on analysis of legal documents.

\section{STUDENTS TRAINING TENDENCY IN THE EU}

The reaction of higher education to global changes in the world was reflected in important declarations, treaties and acts of secondary law, which formed the legal basis for cooperation between higher education and labor market in the EU. The Bologna process is considered to be a strategic European government response to the current economic and geopolitical situation. Today's continuation of the defined objectives of the Bologna process became the strategy "Europe 2020", which clearly identified two interrelated policies - support of growth and jobs and programs for the modernization of higher education in Europe. Thus, the Bologna process, the Lisbon strategy, the strategy "Europe 2020" played a significant role in providing factual powers to create legislation on policies for cooperation between higher education and labour market at EU level that directly affected the process of training. However, the legal basis for the early formation of a modern policy of training of students, which is based on the interaction of higher education with labor market, can be considered the Resolutions of the Council and of the Ministers of Education in 1976, 1980, 1982 and 1985 "Measures to be taken to improve the preparation of young people for work and to facilitate their transition from education to working life”, which were adopted to strengthen youth employment. The Resolution in 1976 was aimed to strengthen consultation and coordination between education and training, job placement and training to facilitate the preparation of young people for their entry into working life. It stressed the need for cooperation between those who are responsible for education, guidance, training and job placement (Resolution of the Council of 13 December 1976).

To reach this purpose, in the next Resolution in 1980 it was decided to run a pilot training program to improve the preparation of young people for work and to facilitate their transition from education to working life (Resolution of the Council of 15 January 1980). In the Resolution of the Council of 12 July 1982 it was first stressed the development of practical cooperation between education, employment and social institutions in order to provide graduates with working experience (Resolution of the Council of 12 July 1982).

Besides these, the Treaty of Lisbon directs the EU to "establish a comprehensive strategy to achieve the objective of a high level of employment, involving all stakeholders." The Article 125 states that member states and the EU will work towards developing a coordinated strategy for employment. The Article 130 provides the establishment of employment committee with consultative status, to promote coordination of the policies of the member states in the field of employment and the labour market (The Lisbon Treaty, 2007).

These legal acts recorded current EU requirements for the modernization of higher education, which aims to ensure full employment by creating new jobs in the Member States, where highly-qualified workers have to come. Institutes of higher education and training should provide graduates with qualitative knowledge and qualifications required in the labour market. 
The system of legal acts adopted by the EU institutions sets the direction for gradual convergence and harmonization of national educational systems of the member states relating to the internal market. Legal acts, mentioned above, show the EU attempt to form a supranational unified policy of training of students in accordance with the requirements of labour market, which is regulated primarily by supranational and national legislation.

The analysis of the legal regulation policy of training at national level shows that the legal acts adopted by the European Parliament and the Council become common for the whole EU. According to the Law "Law on Higher Education for Republic of Serbia”, national standards of higher education must comply with European standards, and accreditation procedures should meet the requirements of the European Higher Education. According to the Article 25 "higher education activities shall be carried out through academic and professional career courses based on the approved and/or accredited study programs for acquiring higher education" (Law on Higher Education for the Republic of Serbia).

In the "Law on Higher Education" in the Republic of Poland there is a clear tendency for higher education cooperation with labour market. Thus, according to to Article 4, HEIs should cooperate with businesses. "Higher education institutions shall co-operate with the socio-economic environment, in particular by conducting research and development for business entities on the basis of organizationally and financially independent economic structures ... as well as through the involvement of employers' representatives in the development of study programs and teaching processes" (ACT of 27 July 2005: p. 7).

Besides, to ensure the right conditions to prepare graduates for professional life in accordance with the demands of the labour market, universities are required to implement information services for professional orientation. These innovations embodied in legislative documents at the national level. Thus, in accordance with the "Decree promulgating the Labour Market Regulation Act (ZUTD)" of the Republic of Slovenia, Article 18 of "Lifelong career orientation", the following services shall "include activities enabling the identification of abilities, competencies and interests for making decisions in the field of employment, education, training and profession selection" (ZUTD).

In our opinion, the "Law on Higher Education" in the Republic of Poland and the "Decree promulgating the Labour Market Regulation Act (ZUTD)" of the Republic of Slovenia is the best example of legislation which is clearly apparent compliance with the norms of the European legislation on the training of students based on the interaction of higher education and training with labour market.

\section{STUDENTS TRAINING TENDENCY IN UKRAINE}

The new law establishes financial principles of higher education system, creates conditions for strengthening cooperation of government agencies and businesses with universities on the principles of autonomy in higher education. An important goal is to prepare competitive human capital for national high-tech innovation and development, self-identity, provide the needs of society, labour market and the state in skilled professionals.

In the new Law on Higher Education of Ukraine we highlight the following innovations. Among the main principles of state policy in the field of higher education is to promote public-private partnerships in higher education and 
public support of universities. The law provides equality between public and private universities. In particular, it introduces free competition between them and defines quality as the main criterion for receiving educational services. Higher education levels and degrees have been changed to adopt them to Bologna process standards. Thus, three cycled higher education with bachelor, master and doctor degrees have been provided. The law gradually cancels such degrees as junior specialist and candidate of science, and instead it introduces the following steps in the educational hierarchy of junior bachelor, bachelor, master, $\mathrm{PhD}$ and doctor of certain sciences. The National Agency for Quality Assurance in Ukraine has been established with the following powers: 1) requirements establishment for Quality Assurance in higher education, regulation development on accreditation of educational programs; 2) requirements development for the academic qualifications of those who acquire degrees, the procedure for the award of specialized academic councils of HEIs (academic institutions); 3 ) development of regulations on accreditation of academic councils and monitoring their activities. The law provides the creation of conditions to increase the mobility of students and teachers. A share of Master's programs in partnership with other Ukrainian HEIs should be raised to $2 \%$ by 2020 for research universities, and with foreign HEIs $5 \%$ by 2020 for research universities. The share of exchange visitors of Ukrainian public HEIs among students should be raised to $5 \%$ by 2020 for all universities. The share of exchange visitors from foreign universities among the total number of students is expected to be $3 \%$ by 2020 . In addition, the new law provides the financial independence of HEIs. They become independent in financial and economic affairs from the state, which should increase their initiative in creating research and innovation organizations. Public HEIs will be able to place their revenue from its educational and scientific activity on the accounts of state banks. Besides, the new law creates conditions for reforming traditional system of state order (Sysoieva S., Mospan N., 2015).

We should state, that in the new Law on Higher Education there is no clear information about higher education and labour market regulation. From one side, the goal of the new Law is to "provide labour market and the state with skilled professionals", from another side, the cooperation with business and employers is not required in educational programs. However, according to the Article 26 "University Objectives", "studying the demand for certain jobs in the labour market" is one of the main objectives of the university (Law on Higher Education of Ukraine, 2014: p. 2). This point only raises questions and requires explanations.

\section{CONCLUSIONS}

The study indicates that today the EU is forming the policy of training students through cooperation of higher education with labour market, which is regulated by national and supranational law. The main feature of this policy compared with other areas of the EU is that this area is increasingly regulated by standardized legislation which provides the use of common approaches and standards. In legal documents is clearly seen direction for the transformation of higher education in order for its supply (graduates) answered market needs (working places).

In Ukraine it is noticed the tendency to modernize the higher education in order to prepare competitive human capital for national high-tech innovation and development, to provide the labour market with skilled workers. Lawmakers direct 
the development of national education system to integration into the European Higher Education Area. The EU experience on students training is a good sample of current trends in global education processes.

\section{REFERENCES}

1. ACT of 27 July 2005 Law on Higher Education. Official Journal of Laws, 164 (1365). (2005). Retrieved from http://www.nauka.gov.pl/g2/oryginal/2013_12/ d687905792f5ff6a3ecf84d7df4f8e57.pdf

2. Labour Market Regulation Act (ZUTD). Retrieved from https://www.ilo. org/dyn/natlex/docs/ELECTRONIC/89477/102807/F-392019526/Labour\%20 Market\%20Regulation.pdf

3. Law on Higher Education of Serbia. Council of Europe Office in Belgrade. Retrieved from http://www.coe.org.rs/eng/activities_sr/?conid=91

4. Law on Higher Education of Ukraine from 01.07.2014 N 1556-VII. Retrieved from http://zakon4.rada.gov.ua/laws/show/1556-18

5. Resolution of the Council and of the Ministers of Education, meeting within the Council, off December 13, 1976. Retrieved from http://eur-lex.europa.eu/ legal-content/EN/TXT/?qid=1466423507695\&uri=CELEX:41976X1230

6. Resolution of the Council and of the Ministers of Education meeting within the Council of 15 January 1980. Retrieved from http://eur-lex.europa.eu/ legal-content/EN/TXT/?qid=1466423507695\&uri=CELEX:41980X0130

7. Resolution of the Council and of the Ministers for Education, meeting within the Council, of 12 July 1982. Retrieved from http://eur-lex.europa.eu/ legal-content/EN/TXT/?qid=1466423507695\&uri=CELEX:41982X0728

8. Sysoieva, S., Mospan, N. (2015). New Law on Higher Education in Ukraine: Innovations and Risks. Didactica Slovenica, 30 (3-4), 166-173. Retrieved from http://www.pedagoska-obzorja.si/revija/Vsebine/PDF/DSPO_2015_30_03.pdf

9. The Lisbon Treaty. Title XII. Retrieved from http://www.lisbon-treaty. $\mathrm{org} / \mathrm{wcm} /$ the-lisbon-treaty/treaty-on-the-functioning-of-the-european-unionand-comments/part-3-union-policies-and-internal-actions/title-xii-educationvocational-training-youth-and-sport.html 